\title{
Wet Coffee Processing Discharges Affecting Quality of River Water at Kayanza Ecological Zone, Burundi
}

\author{
Emile Bisekwa1 ${ }^{1,2}$, Paul M. Njogu' ${ }^{1}$, Taye Kufa-Obso ${ }^{3}$ \\ ${ }^{1}$ Institute of Energy and Environmental Technology, JKUAT, Nairobi, Kenya \\ ${ }^{2}$ Burundi Institute of Agricultural Sciences (ISABU), Bujumbura, Burundi \\ ${ }^{3}$ International Institute of Tropical Agriculture, Bujumbura, Burundi \\ Email: ^emilebisekwa@gmail.com
}

How to cite this paper: Bisekwa, E., Njogu, P.M. and Kufa-Obso, T. (2021) Wet Coffee Processing Discharges Affecting Quality of River Water at Kayanza Ecological Zone, Burundi. Open Journal of Applied Sciences, 11, 707-721.

https://doi.org/10.4236/ojapps.2021.116052

Received: May 10, 2021

Accepted: June 26, 2021

Published: June 29, 2021

Copyright $\odot 2021$ by author(s) and Scientific Research Publishing Inc. This work is licensed under the Creative Commons Attribution International License (CC BY 4.0).

http://creativecommons.org/licenses/by/4.0/

\begin{abstract}
Wet coffee processing leads to the generation of large volumes of wastewater, whose discharge to the environment leads to pollution of freshwater bodies. Kayanza is a major coffee growing area in Burundi with more than 40 wet coffee processing factories (WCPF) that discharge effluents directly to receiving water bodies without treatment. This study was carried out to assess the effect of coffee wastewater on the physicochemical properties of receiving waterbodies in Kayanza coffee growing ecological zone. Currently, no study has been done to analyze the effluent from the WCPF and assess the level of pollution. This study will therefore provide valuable data on the water pollution from coffee processing plants. Ten (10) rivers in the Kayanza coffee growing zone were studied during the months of April and June, 2020. Water samples were collected upstream (U) and downstream (D) of the effluent discharge points in triplicate. Samples were analyzed for $\mathrm{pH}$, Chemical Oxygen Demand (COD), Biochemical Oxygen Demand $\left(\mathrm{BOD}_{5}\right)$, Temperature, Salinity, Electrical Conductivity (EC), Total Dissolved Solids (TDS), Dissolved Oxygen (DO), Total Suspended Solids (TSS), Nitrates, Nitrites, Lead $(\mathrm{Pb})$, Copper $(\mathrm{Cu})$, Chlorides and Ammonium ions using standard methods. Physical parameters were analyzed in situ whereas chemical parameters were analyzed in the laboratories in Burundi Institute of Agricultural Sciences (ISABU) and University of Burundi. Data were analyzed using R-studio-1.0.153, GenStat 64-bit Release 14.1 and SSPS. Results on the physicochemical parameters indicated that coffee factory effluent has a polluting potential during coffee processing peak. The concentrations of the physicochemical parameters were significantly $(\mathrm{p}<0.05)$ higher downstream $(\mathrm{D})$ compared to upstream $(U)$ of the river water sampling points. All downstream sites had
\end{abstract}


$\mathrm{COD}, \mathrm{BOD}_{5}$, TSS and $\mathrm{pH}$ values above allowable limits set by $\mathrm{WHO}$ and $\mathrm{Bu}-$ rundi. The polluting impact of public wet coffee processing factories was significantly higher than that of private and cooperatives owned factories $(\mathrm{p}<$ 0.05). Measures should be taken in order to protect water bodies.

\section{Keywords}

Wastewater, Water Pollution, Kayanza Zone, Wet Coffee Processing

\section{Introduction}

In developing countries, scarcity and water pollution constitute a primary challenge for sustainable water resources management. Coffee effluent's impact on water quality is of great concern. This is because it has been observed that the quality of water has a great effect on human health, exposing the environment to several hazards [1]. It becomes pertinent to carry out Environmental Impact Assessment (EIA) for any proposed wet coffee processing plants and Environmental Audits for existing factories. Inefficient use of water, contaminated water sources and use of polluted water in the wet processing of coffee cherries are all major issues in Burundi and other coffee producing countries [2] [3]. Currently, none of the wet coffee processing factories in Kayanza, has installed appropriate wastewater treatment technologies to improve the quality of the coffee wastewater to meet the set discharge standards.

By 2020, Kayanza had more than 40 wet coffee processing (WCP) plants (18 Publicly, 12 Privately and 9 Cooperatively owned functional wet coffee processing factories). Only Private and Cooperative owned factories had begun to operate the coffee wastewater treatment systems. The common wet coffee processing method used in Kayanza zone produces a significant amount of wastewater with a high pollution load because wet coffee processing factories are one of the significant consumers of water and produces a large amount of wastewater. This wastewater is later discharged into the river system polluting the water and negatively impacting the natural ecosystem and health of the local communities. Coffee wastewater contains high concentrations of organic matter, suspended matter and is highly acidic [4]. Organic load is measured in terms of COD (Chemical Oxygen Demand) and BOD $_{5}$ (Biological Oxygen demand during five days), while acidity in terms of $\mathrm{pH}$, and suspended matter in terms of total suspended solids (TSS). Considering the volume generated and the pollutants from the coffee wastewater, the wet coffee processing plant represents one of the main contributors to severe pollution problems. It was reported that all public wet coffee processing factories, even those with wastewater treatment plants do not treat the wastewater appropriately and discharge untreated, colored and acidic effluent into the nearby water bodies, streams and open land [4] [5]. This can have a serious negative impact on both the health of the surrounding population 
as well as the quality of water used to irrigate the crops. Finally, the use of polluted water sources for washing coffee can result in bacterial diseases of coffee lots, leading to their rejection on the international market due to failure to comply with sanitary and phyto-sanitary (SPS) standards.

Furthermore, the perfection of water management in coffee supply is progressively being discussed as an important factor for market access. A number of certifications, including Rainforest Alliance and Fair Trade, as well as buyer programs such as Starbuck's C.A.F.E. program have begun to integrate and audit water management practices throughout their supply chain, and it is likely to become an important factor for reaching and keeping certification in the future [1] [6]. In addition to certification programs, the incorporation of appropriate water management techniques is also being considered by the Specialty Coffee Association of America (SCAA) as a new requirement for coffee to receive "specialty" certification [1] [7]. The failure to implement better water management practices in Burundi could thus have serious implications in terms of achieving the necessary upgrading into the specialty coffee segment.

No studies have investigated this issue in Burundi to assess the extent of the water pollution and suggest solutions and recommendations. This research was therefore important to evaluate the effect of wet coffee processing factories' effluents on physicochemical properties of receiving water bodies in Kayanza, Burundi.

\section{Materials and Methods}

\subsection{Study Area}

The study was conducted in Kayanza Province, one of the coffee growing ecological zone in Burundi. Kayanza province is located North of Burundi (Figure $1 \&$ Figure 2) and lying between latitude of $2.9235^{\circ}$ South and longitude of $29.6278^{\circ}$ East. The area ranges from 1500 to 1850 meters above sea level with a temperature range of $15^{\circ} \mathrm{C}$ to $17^{\circ} \mathrm{C}$. The area receives rainfall between 1200 to $1400 \mathrm{~mm}$ annually.

\subsection{Water Sampling and Preservation}

Samples were collected during peak seasons of April/Wet season and June/Dry season. Ten (10) rivers were selected in Kayanza coffee growing ecological zone according to Mugenda and Mugenda approach [8]. In order to assess the effect of the wastewater from the factories on the physicochemical properties of the receiving water bodies in Kayanza province, water samples were taken from rivers/streams that receive wastewater from the wet coffee processing factories at upstream and downstream of the discharge points (Table $1 \&$ Figure 3 ).

The samples were collected using sampling procedures described in APHA, 1995 [9]. Onsite pretreatment was done for all parameters analyzed in the laboratory except water samples for the analysis for TSS, Chlorides and $\mathrm{BOD}_{5}$. All samples were collected using pre-cleaned plastic bottles. 


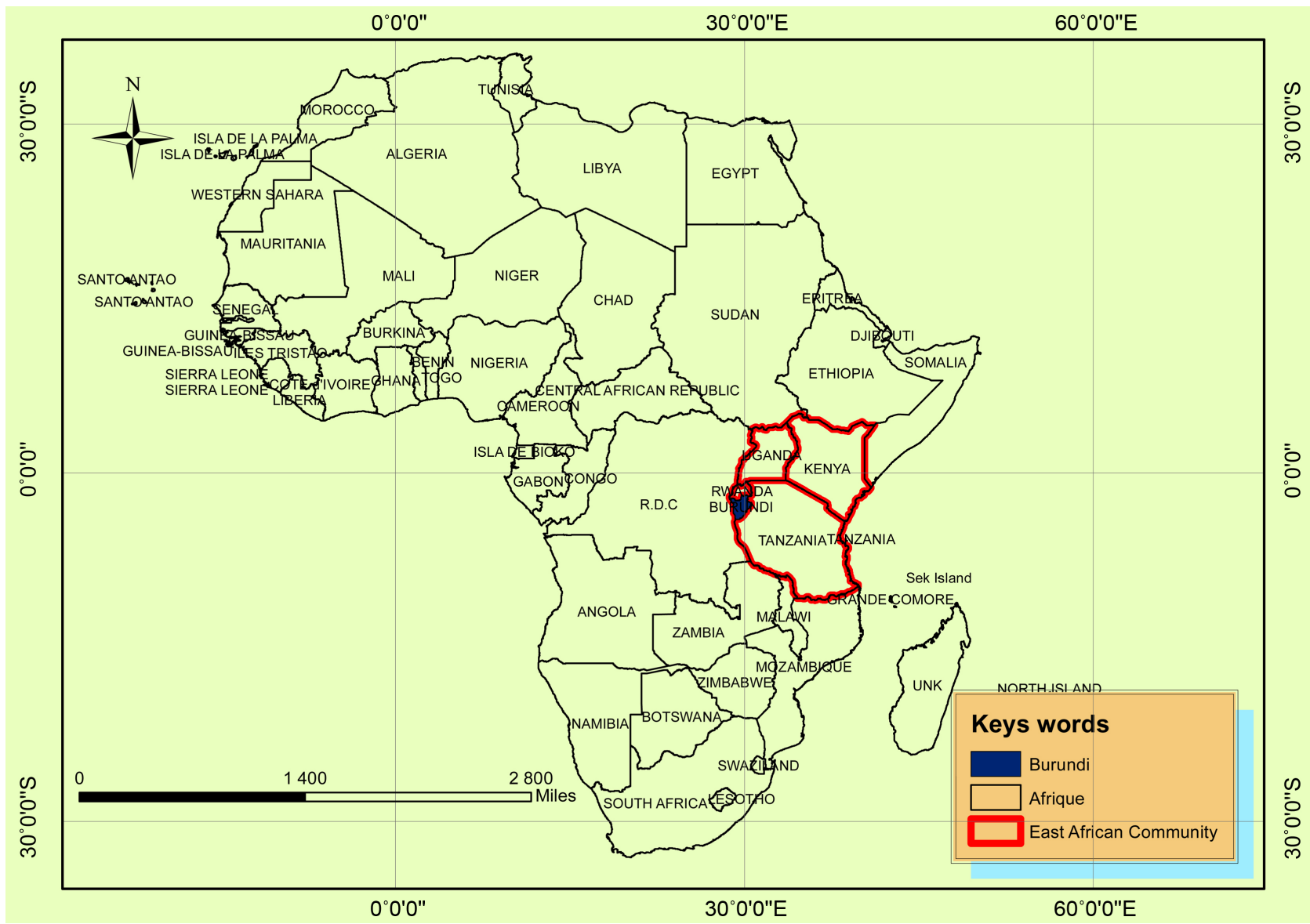

Figure 1. Map of africa showing Burundi.

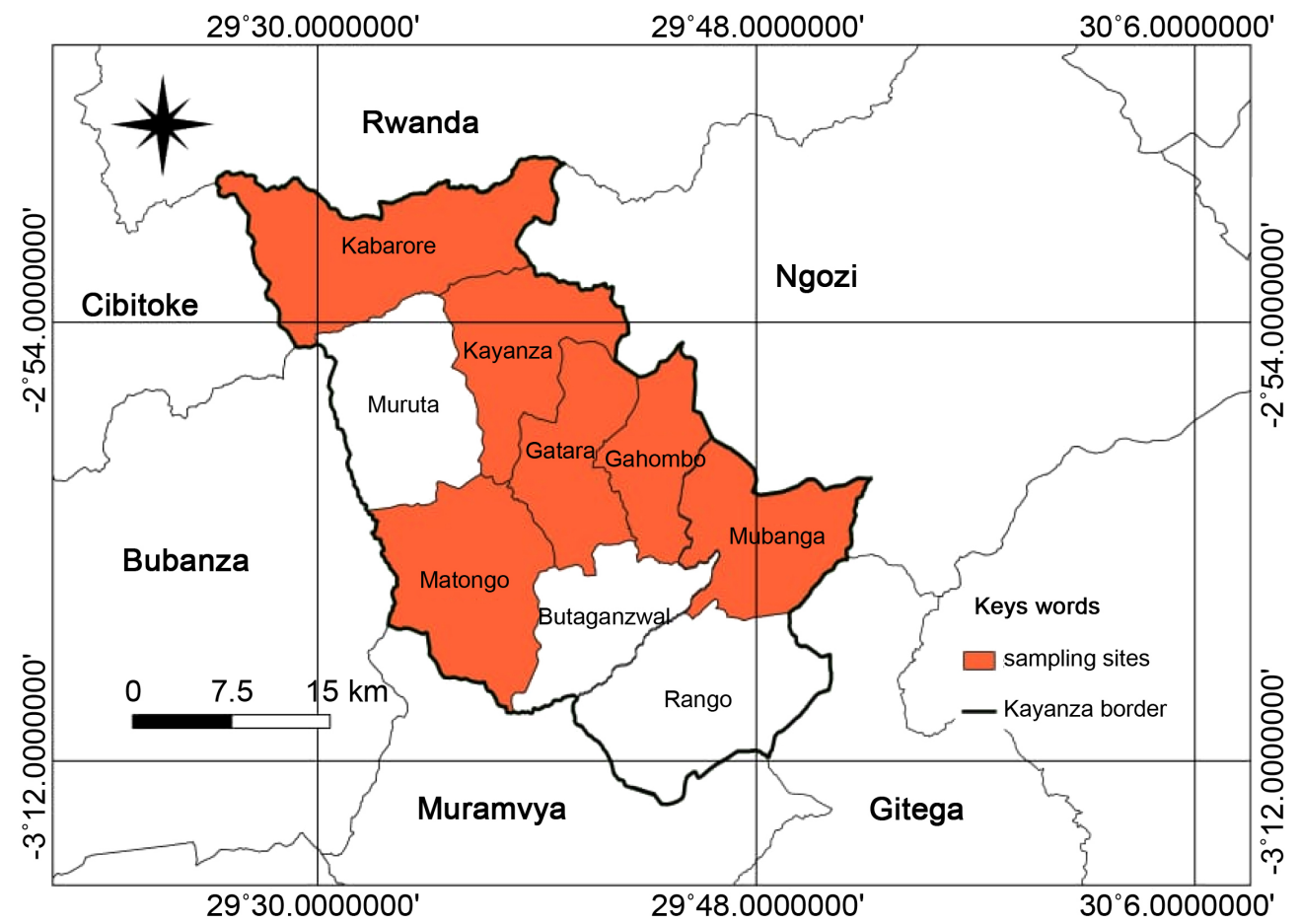

Figure 2. Map of Kayanza province indicating sampling sites. 
Table 1. Samples collection sites.

\begin{tabular}{ccc}
\hline Sampling point & $\begin{array}{c}\text { Wet coffee } \\
\text { processing owners }\end{array}$ & $\begin{array}{c}\text { Location in } \\
\text { Kayanza Province }\end{array}$ \\
\hline Nyakagezi (A) River & Public & Muhanga Commune \\
Ruvubu2 (B) River & Public & Gatara Commune \\
Gisiza (C) River & Public & Gahombo Commune \\
Nyandibika (D) River & Public & Muhanga Commune \\
Ruvubu (E) River & Private & Gatara Commune \\
Nantangaro (F) River & Private & Kayanza Commune \\
Ntampanda (G) River & Private & Kayanza Commune \\
Nabadandi (H) River & Cooperative & Kayanza Commune \\
Nakagogo (I) River & Cooperative & Matongo Commune \\
Kurugomero (J) River & Cooperative & Kabarore Commune \\
\hline
\end{tabular}

\subsection{Experimental Design}

Samples were analyzed in triplicates. Physical and chemical analyses were carried out in order to assess the effect of coffee processing wastewater being discharged without adequate treatment.

\subsection{Analytical Procedures}

Samples were analyzed onsite for $\mathrm{pH}$, Temperature $\left(\mathrm{T}^{\circ}\right)$, salinity, Electrical Conductivity (EC), total dissolved solids (TDS) and dissolved oxygen (DO) using Trace2o Hydrocheck HC1000 multi-parameter Electrochemical Meter kit T20AN-P270. Whereas samples for analysis of chloride $\left(\mathrm{Cl}^{-}\right)$, Nitrite $\left(\mathrm{NO}_{2}^{-}\right)$, Nitrate $\left(\mathrm{NO}_{3}^{-}\right)$, Ammonium $\left(\mathrm{NH}_{4}^{+}\right)$, Phosphate $\left(\mathrm{PO}_{4}^{3-}\right)$, Lead $(\mathrm{Pb})$, Copper $(\mathrm{Cu})$, Total Suspended Solids (TSS), Chemical Oxygen Demand (COD) and Biochemical Oxygen Demand $\left(\mathrm{BOD}_{5}\right)$ were transported to the laboratory of Burundi Institute of Agricultural Sciences (ISABU) and University of Burundi for analysis. The methods of analysis used were those described by APHA, 2005 [9]. Phosphates, nitrites and nitrates were analyzed by UV-vis spectrophotometer (BK-UV 1800PC Biobase) with $1 \mathrm{~cm}$ matched quartz cells in the Laboratory (LASPA) according to the standard methods [9] [12]. COD Was analyzed using colorimetric method NOVA 60 according to the standards methods and $\mathrm{BOD}_{5}$ [9] by manometric method using amber colored bottles topped with an "OXYTOP»" head.

TSS was determined by filtration (Filtered with whatman $\mathrm{N}^{\circ} 41$ ) of a volume of water (1liter) and dried at $105^{\circ} \mathrm{C}$ in an oven WT-Binder 7200 Tuttling/Germany during $24 \mathrm{~h}$. TSS was given by the following formula [12]:

$$
\operatorname{TSS}(\mathrm{mg} / \mathrm{l})=\frac{\left(M_{1}-M_{0}\right) \times 100}{V_{\text {sample }}}
$$

where $M_{0}=$ Mass of the filter before use (mg/l); $M_{1}=$ Mass of the filter after use $(\mathrm{mg} / \mathrm{l}) ; V_{\text {sample }}=$ Volume of water used (in $\left.\mathrm{ml}\right)$. 


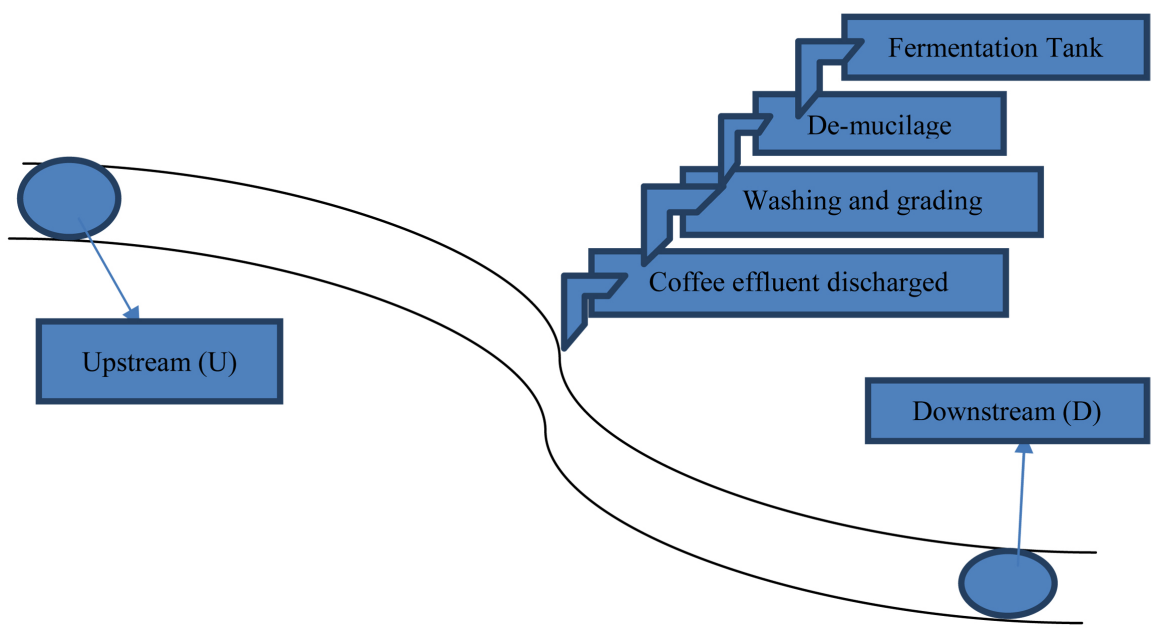

Figure 3. Map showing flow diagram of coffee factory and river water sampling points [13].

Ammonium ions were analyzed in an alkaline environment, ammonia was displaced, entrained by water vapor and then carried out on the distillate by volumetric method. The ammonium content expressed in milligrams per liter was given by the following relationship [12]:

$$
\mathrm{NH}_{4}^{+}(\mathrm{mg} / \mathrm{l})=\frac{\left(V_{1}-V_{0}\right) \times 0.05 \times 18 \times 100}{V_{\text {sample }}}
$$

where

$V_{1}=$ Volume of titrant used for titration of sample; $V_{2}=$ Volume of sample and $V_{0}=$ Volume of titrant used for titration of blank.

The wastewater samples were analyzed for dissolved heavy metal concentrations using Flame Atomic Absorption Spectrophotometer Perkin-Elmer Analyst 400 (Hi-tech Detection systems) directly after filtration with a Whatman $\mathrm{N}^{\circ} 41$ filter paper. The concentrations of chloride were determined by titrimetric method, the equipment's used were conical flask, pipette and Burette. The chloride was determined using [9].

$$
\mathrm{Cl}(\mathrm{mg} / \mathrm{l})=\frac{X \times 0.01 \times 35.45 \times 1000}{V_{\text {sample }}}
$$

where $X=$ Volume of titrant used for titration of sample; $V_{\text {sample }}=$ Volume of sample.

\subsection{Data Processing and Analysis}

The data were statistically analyzed using MS-Excel 2016, R-studio-1.0.153, GenStat 64-bit Release 14.1 and SPSS. This was subjected to statistical tests of significance where paired t-test to establish whether there was any significant difference between concentration levels during the dry and wet seasons at the different sampling sites. Analysis of variance was used to compare the mean values of observation based on sites. All statistical tests were done at 95\% confidence level $(\mathrm{p}<0.05)$ 


\section{Results and Discussions}

The comparison of the value of water quality parameters using box and whisker plot are presented (Figure 4) and the overall assessment and classification of stagnant and running surface water according to their river water quality have been given in Table 2 to compare the pollution level of wastewater generated from the coffee processing plant and for the nearby waterbodies receiving this wastewater.

Higher concentration of the various physicochemical paremeters was obtained at downstream (D) sites than upstream (U) according to the values presented in Figure 4. However, higher $\mathrm{pH}$ values were obtained upstream and lower $\mathrm{pH}$ values were found at downstream locations for most of the rivers/streams sampled.

$\mathrm{pH}$ was in the range of $6.0-6.8$ with a mean of $6.48 \pm 0.10$ upstream and 4.5 6.6 with a mean of $5.75 \pm 0.81$ during wet season (Month of April) while during dry season (Month of June), $\mathrm{pH}$ varied from $6.1-6.8$ with a mean of $6.50 \pm 0.22$ and from $5.2-6.0$ with a mean of $5.70 \pm 0.49$ respectively for the upstream and downstream. High $\mathrm{pH}$ values (6.48 - 6.50) were observed in the upstream and low values (5.2 - 5.75) in down streams sites, these indicated clearly the negative impact of wet coffee processing factories in Kayanza coffee growing ecological zones in Burundi. This low $\mathrm{pH}$ at downstream locations was probably due to the discharge from wet coffee processing factories. The $\mathrm{pH}$ of the water samples from the upstream and downstream sites generally showed that there was significant difference $(\mathrm{p}<0.05)$. This difference could be attributed to the agricultural runoff and to the coffee waste water discharged without treatment. The $\mathrm{pH}$ values did not differ significantly $(\mathrm{p}<0.05)$ within the seasons. The $\mathrm{pH}$ levels were below the permissible limit at all downstream sampling sites. Low $\mathrm{pH}$ is

Table 2. Overall assessment and classification of stagnant and running surface water according to their river water quality [10] [11].

\begin{tabular}{cccccc}
\hline $\mathbf{N}^{\bullet}$ & Parameters & $\mathbf{1 A}$ & $1 \mathrm{~B}$ & 2 & 3 \\
\hline 1 & Temperature $\left({ }^{\circ} \mathrm{C}\right)$ & $\leq 20$ & $20-22$ & $22-25$ & $25-30$ \\
2 & $\mathrm{pH}$ & $6.5-8.5$ & $6.8-8.5$ & $6-9$ & $8.5-9.5$ \\
3 & $\mathrm{TSS}(\mathrm{mg} / \mathrm{l})$ & $\leq 30$ & $\leq 30$ & $\leq 30$ & $30-70$ \\
4 & Nitrates $(\mathrm{mg} / \mathrm{l})$ & - & - & $\leq 44$ & $44-100$ \\
5 & Phosphates $(\mathrm{mg} / \mathrm{l})$ & $<0.1$ & $0.1-0.3$ & $0.3-0.5$ & $0.5-3$ \\
6 & $\mathrm{COD}(\mathrm{mg} / \mathrm{l})$ & $<20$ & $20-25$ & $25-40$ & $40-80$ \\
7 & $\mathrm{BOD}(\mathrm{mg} / \mathrm{l})\left(5 \mathrm{days}\right.$ at $\left.20^{\circ} \mathrm{C}\right)$ & $<3$ & $3-5$ & $5-10$ & $10-25$ \\
8 & $\mathrm{EC}$ & $\leq 400$ & $400-750$ & $750-1500$ & $1500-3000$ \\
9 & $\mathrm{DO}(\mathrm{mg} / \mathrm{l})$ & $>7$ & $5-7$ & $3-5$ & $<3$ \\
10 & $\mathrm{NH}(\mathrm{mg} / \mathrm{l})$ & $\leq 0.1$ & $0.1-0.5$ & $0.5-2$ & $2-8$ \\
\hline
\end{tabular}

1A: no polluted water; 1B: good water quality; 2 : fair water quality; 3 : poor water quality. 

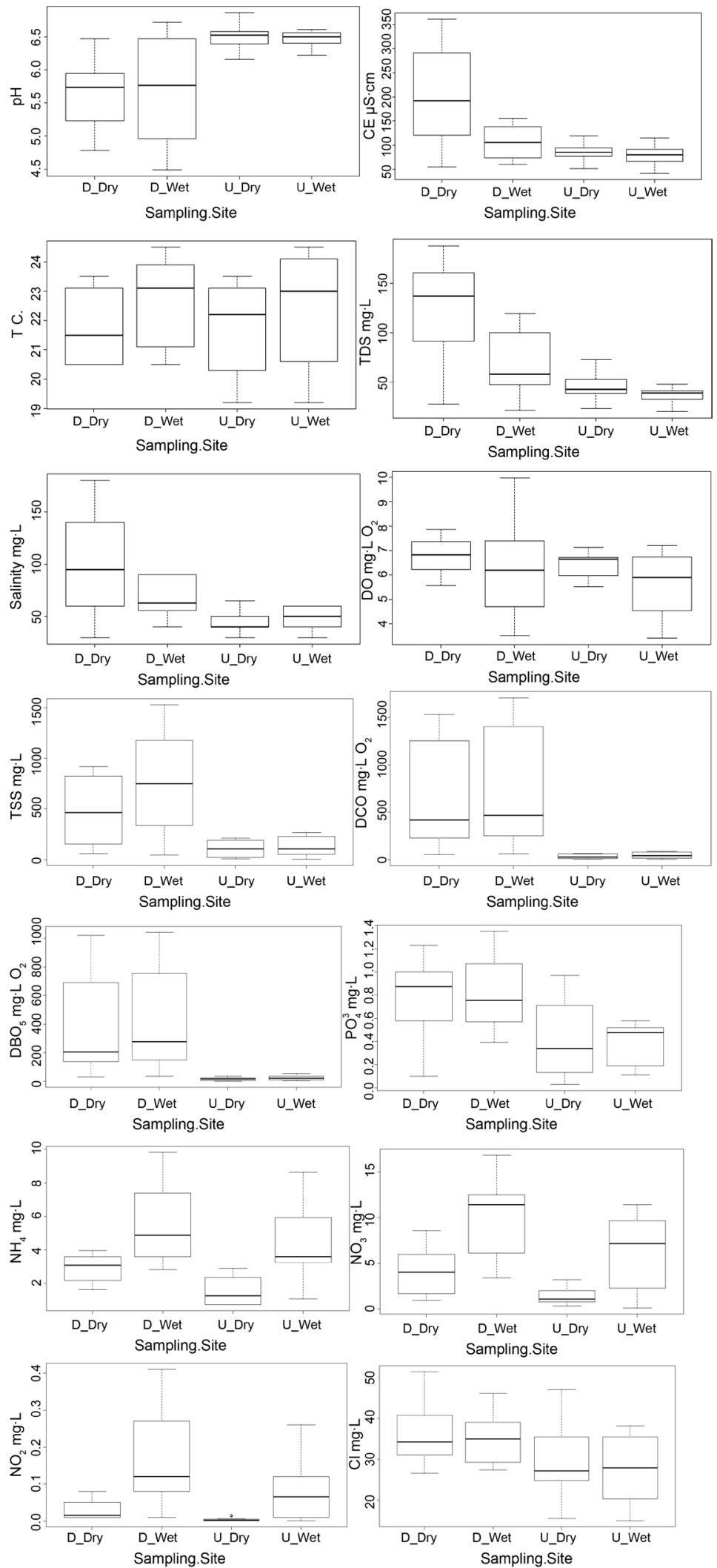

Figure 4. Box and whisker plot of water quality variables of the at upstream site during Wet and Dry seasons (U_Wet \& D_Dry) and at downstream during wet and dry seasons (D_Wet \& D_Dry) of the WCPF. 
especially harmful to immature fish and insects. Acidic water also speeds the leaching of heavy metals harmful to fish [14]. This finding is in consistent with similar study done in Jimma zone by Dejen Yemane Tekle et al., 2015 [15], reported that high $\mathrm{pH}$ was observed at upstream sites than downstream sites. Unlike the other parameters, the amount of $\mathrm{pH}$ was found high in the upstream site (7.11) and reduced $\mathrm{pH}$ values at downstream locations of most rivers.

The temperature at downstream of the rivers during the wet and dry seasons was found to be within the range of $20.8^{\circ} \mathrm{C}-24.2^{\circ} \mathrm{C}$ with a mean of $22.7^{\circ} \mathrm{C} \pm$ $1.38^{\circ} \mathrm{C}$ and $20.5^{\circ} \mathrm{C}-23.5^{\circ} \mathrm{C}$ with a mean of $21.8^{\circ} \mathrm{C} \pm 1.24^{\circ} \mathrm{C}$ respectively. This displayed wide variations among sampling locations and did not change significantly $(\mathrm{p}<0.05)$ during seasons. The temperature in the upstream rivers ranged from $19.2^{\circ} \mathrm{C}-23.9^{\circ} \mathrm{C}$ with a mean of $22.5^{\circ} \mathrm{C} \pm 1.76^{\circ} \mathrm{C}$ in wet season as compared to the results recorded in dry season which ranged from $19.2^{\circ} \mathrm{C}-22.5^{\circ} \mathrm{C}$ with a mean of $21.8^{\circ} \mathrm{C} \pm 1.54^{\circ} \mathrm{C}$ varied from one river to another in Kayanza agro ecological Zones in Burundi and were below $25^{\circ} \mathrm{C}$, which is the set limit for no risk as per the WHO, FAO quality guidelines for discharging effluent to natural surface water bodies. These results are in agreement with preceding work undertaken by Hadis and Devi (2007) in Jimma zone in which the water temperature downstream of receiving waterbodies after receiving coffee effluents was reported as $22^{\circ} \mathrm{C}$. Based on the findings and on the guidelines, the temperature of the effluent did not pose any threat to the water ecosystem of the receiving water bodies [10] [11]. There was no significant difference in temperature values between the two seasons at $95 \%$ confidence interval.

The EC of the water reflects of quantity of dissolved ionic constituents. The EC profile of the upstream and downstream water bodies varied significantly $(\mathrm{p}<$ $0.05)$ and ranged from $41.9-114.5 \mu \mathrm{S} / \mathrm{cm}$ with a mean of $77.5 \pm 19.73 \mu \mathrm{S} / \mathrm{cm}$ and from $47.6-184.1 \mu \mathrm{S} / \mathrm{cm}$ with a mean of $85.6 \pm 18.62 \mu \mathrm{S} / \mathrm{cm}$ respectively up stream's results recorded in wet and dry seasons. While the down stream's results recorded in wet and dry seasons ranged respectively from 42.6 - 277.7 $\mu \mathrm{S} / \mathrm{cm}$ with a mean of $104.1 \pm 34.25 \mu \mathrm{S} / \mathrm{cm}$ and from 54.6 to $360.3 \mu \mathrm{S} / \mathrm{cm}$ with a mean of $206.5 \pm 102.13 \mu \mathrm{S} / \mathrm{cm}$. These values were low all long the sampling points as compared to the provisional river water quality limit [10] [11]. The high EC downstream can be attributed to the high mucilage from wet coffee processing effluents. A sudden increase or decrease in conductivity in body of water can indicate pollution Agricultural runoff or sewage could increase EC due to the additional of chlorides, phosphates, Nitrates. In this case the additional of dissolved solids will have a negative impact on water quality.

The mean concentration of TDS was found to be in the range of 20.6 - 57.4 $\mathrm{mg} / \mathrm{l}$ with a mean of $37.0 \pm 7.58 \mathrm{mg} / \mathrm{l}$ and 23.8 to $92.3 \mathrm{mg} / \mathrm{l}$ with a mean of $45.2 \pm$ $13.02 \mathrm{mg} / \mathrm{l}$ respectively for up stream's results recorded in Wet and Dry seasons while the down stream's results recorded in Wet and Dry seasons varied respectively from $21.3-137.7 \mathrm{mg} / \mathrm{l}$ with a mean of $67.8 \pm 31.87 \mathrm{mg} / \mathrm{l}$ and from 27.7 to $186.9 \mathrm{mg} / \mathrm{l}$ with a mean of $124.1 \pm 48.6 \mathrm{mg} / \mathrm{l}$. The TDS of the water samples generally varied significantly $(\mathrm{p}<0.05)$ through the study period. High TDS $(67.8$ - 
$124.1 \mathrm{mg} / \mathrm{l})$ were found at the downstream sites of the discharged points. The relatively higher amount of TDS at the downstream sites might be attributed by the high mucilage from coffee processing effluents. The results show that the results of the current study agree with the findings reported by Tadesse M. E. \& Haddis A., 2016 and Dejen Yemane Tekle et al., 2015 [15]. However, the effluents quality did appear to be compliant with the regulations of TDS [4]. Thus the parameter indicated that the water was suitable for direct domestic use [10] [11]. The high values of TDS can be toxic to flesh water animals causing osmotic stress and can give increase to obnoxious odors from the decay of organic matter and vulgar smell [15].

The DO levels in the upstream of the rivers water were found within the range of $3.47-7.13 \mathrm{mg} / \mathrm{l}$ with a mean of $5.70 \pm 1.24 \mathrm{mg} / \mathrm{l}$ and from 3.40 to $7.10 \mathrm{mg} / \mathrm{l}$ with a mean of $6.22 \pm 1.03 \mathrm{mg} / \mathrm{l}$ for the results recorded respectively in wet and Dry seasons and changed significantly during the seasons. DO concentrations in the downstream of the rivers water ranged from 3.58 to $11.2 \mathrm{mg} / \mathrm{l}$ with a mean of $6.42 \pm 2.17 \mathrm{mg} / \mathrm{l}$ and from 3.58 to $7.81 \mathrm{mg} / \mathrm{l}$ with a mean of $6.55 \pm 1.17 \mathrm{mg} / \mathrm{l} \mathrm{re}-$ spectively for the results recorded in April and June and these express wide variations between samples from different sites. These results changed significantly $(\mathrm{p}<0.05)$. Low oxygen conditions can cause a variety of water quality problems and suffocation of fish and other aquatic animals and a DO level that is too high or too law can harm aquatic life and affect water quality. Based on the guideline, DO of water river at all the sampling sites in Kayanza coffee growing ecological zone does not appear to pose any treat to the homeostatic of water bodies.

Generally high values were recorded at downstream whether in wet and dry seasons as compared to upstream sites. The mean TSS values in the upstream locations of river water during wet and dry seasons were found within range of $8.05-467.7 \mathrm{mg} / \mathrm{l}$ with a mean of $131.49 \pm 92.98 \mathrm{mg} / \mathrm{l}$ and $10.5-501.4 \mathrm{mg} / \mathrm{l}$ with a mean of $106.1 \pm 76.92 \mathrm{mg} / \mathrm{l}$ respectively and changed significantly $(\mathrm{p}<0.05)$ due to the seasons in Kayanza agro ecological zones in Burundi. This change could be to the various organic material came to the rivers by runoff during wet season. At downstream sites, the TSS was in the range of $48.6-1524.3 \mathrm{mg} / \mathrm{l}$ with a mean of $771.5 \pm 504.75 \mathrm{mg} / \mathrm{l}$ and from $59.0-917.7 \mathrm{mg} / \mathrm{l}$ with a mean of $457.4 \pm$ $321.31 \mathrm{mg} / \mathrm{l}$ in wet and dry seasons respectively with wide variations between sites. These values were in the agreement with the data reported by Dejen Yemane Tekle et al., 2015 [15]. There was significant difference in overall TSS between the two seasons at $95 \%$ confidence level. The difference is attributable to coffee solids waste during coffee processing. Based on the WHO [16] standard and the overall assessment criteria for river water quality [10], the TSS concentrations along all down streams locations/sites were almost above than the acceptable limit, which indicated the pollution of the rivers. Based on the standard limit values, TSS in all sampling points (rivers) should adversely affect the use of water for various purposes [17]. High TSS can cause turbidity in the river and may change the habitat of aquatic microorganisms. 
During wet season, the concentration of salinity in the upstream was in the range of $30-60.2 \mathrm{mg} / \mathrm{l}$ with a mean $48.5 \pm 8.52 \mathrm{mg} / \mathrm{l}$ and river water downstream the concentrations were in the range of $40.9-130.0 \mathrm{mg} / \mathrm{l}$ with a mean of $68.8 \pm 17.12 \mathrm{mg} / \mathrm{l}$ and varied widely between sites. The highest salinity values were observed at downstream sites whether in wet and dry seasons. The concentrations of salinity in upstream and downstream samples varied widely respectively from $30.0-90.2 \mathrm{mg} / \mathrm{l}$ with a mean of $45.5 \pm 10.28 \mathrm{mg} / \mathrm{l}$ and from 50.0 to $180.0 \mathrm{mg} / \mathrm{l}$ with a mean of $100.0 \pm 47.05 \mathrm{mg} / \mathrm{l}$. At downstream, there was significant difference between the two seasons $(\mathrm{p}<0.05)$. This difference might be due the coffee effluents discharged to the water receiving bodies without any treatment. High salinity can decrease plant growth and water quality and degraded stock of water supplies.

The COD concentration in the downstream of rivers water was found within range of $59.8-1700.6 \mathrm{mg} / \mathrm{l}$ with a mean of $776.5 \pm 651.58 \mathrm{mg} / \mathrm{l}$ and $60.7-1250.1$ $\mathrm{mg} / \mathrm{l}$ with a mean of $693.7 \pm 583.83 \mathrm{mg} / \mathrm{l}$ respectively for the results recorded in wet and dry seasons with wide variations between sites and locations. The highest average mean values of $\mathrm{COD}$ and $\mathrm{BOD}$ were observed at the upstream sites whether in wet and dry $(45.1 \pm 0.71)$ at Nyakagezi river, $(75.3 \pm 0.58 \mathrm{mg} / \mathrm{l})$ at Kagogo river, $(60.3 \pm 0.58 \mathrm{mg} / \mathrm{l})$ at Ruvubu2, $(65.3 \pm 0.58 \mathrm{mg} / \mathrm{l})$ at Nyandibika, $(120.3 \pm 0.15 \mathrm{mg} / \mathrm{l})$ at Nantangaro river and $(45.3 \pm 0.58 \mathrm{mg} / \mathrm{l})$ at Kurugomero river, this indicated heavy load of organic and inorganic pollution that require more oxygen to oxidize under increased thermal conditions [18]. The high mean concentrations COD $(693.70$ - $776.5 \mathrm{mg} / \mathrm{l})$ observed at downstream sites as compared to the upstream sites, respectively indicated the pollution strength of the receiving water bodies. There was also significant difference between the two seasons at $95 \%$ confidence interval. This difference was caused by the various large amount of chemical and biological demanding substances released from the wet coffee processing factories into the rivers without any treatment in Kayanza coffee growing ecological zones in Burundi. Based on the WHO standards, the COD concentration along downstream sites were higher than the acceptable limit which indicated the pollution of the river [10] [16]. Our findings are in agreement with what was reported by Devi, 2019; Dejen Yemane Tekle et al., 2015 [15] and Ejeta, T. M., \& Haddis, A. (2016) [1].

$\mathrm{BOD}_{5}$ was in the range of $3.00-53.0 \mathrm{mg} / \mathrm{l}$ with a mean of $24.0 \pm 17.65 \mathrm{mg} / \mathrm{l}$ and $2.10-46.0 \mathrm{mg} / \mathrm{l}$ with a mean of $15.52 \pm 10.46 \mathrm{mg} / \mathrm{l}$ upstream respectively in wet and dry seasons whereas $\mathrm{BOD}_{5}$ was at downstream in the range of 35.07 $1040.3 \mathrm{mg} / \mathrm{l}$ with a mean of $433.3 \pm 360.88 \mathrm{mg} / \mathrm{l}$ and $47.0-1020.4 \mathrm{mg} / \mathrm{l}$ with a mean of $399.8 \pm 637.36 \mathrm{mg} / \mathrm{l}$ respectively in wet and wry seasons (Months of April \& June). The effluent discharged from the wet coffee processing factories in Kayanza, may have increased the $\mathrm{COD}$ and $\mathrm{BOD}_{5}$ concentrations of the receiving water bodies. The downstream rivers water $\mathrm{COD}$ and $\mathrm{BOD}_{5}$ were high than $40 \mathrm{mg} / \mathrm{l}$ and $10 \mathrm{mg} / \mathrm{l}$ respectively recommended by WHO [16], overall assessment and classification of stagnant and running surface water according to 
their river water quality [10]. The values are in the agreement with what was reported by the others researchers such as Devi, 2019; Dejen Yemane Tekle et al., 2015 [15] and Ejeta, T. M., \& Haddis, A. (2016) [1]. Water with high concentrations of $\mathrm{BOD}_{5}$ can be worming sign of an algal bloom, however, in which circumstance, high oxygen concentration during the day are likely to be followed by low oxygen concentration at night and very low concentrations when the broom breakdowns. There was significant difference between the two seasons at $\mathrm{p}<0.05$, the difference could be attributed to the dilution effect during wet season.

The range of phosphates concentrations varied widely from $0.09-1.10 \mathrm{mg} / \mathrm{l}$ with a mean of $0.40 \pm 0.17 \mathrm{mg} / \mathrm{l}$ and from $0.03-1.94 \mathrm{mg} / \mathrm{l}$ with a mean of $0.41 \pm$ $0.34 \mathrm{mg} / \mathrm{l}$ respectively along upstream of rivers water in wet and dry seasons with wide variations between sites. Whereas the phosphates were in the range of $0.39-4.60 \mathrm{mg} / \mathrm{l}$ with a mean of $0.82 \pm 0.30 \mathrm{mg} /$ and $0.10-4.26 \mathrm{mg} / \mathrm{l}$ with a mean of $0.78 \pm 0.34 \mathrm{mg} / \mathrm{l}$ downstream in wet and dry seasons with wide variations between sites respectively in wet and dry seasons. The phosphates concentration changed significantly $(\mathrm{p}<0.05)$ due the seasons. Comparison of the result obtained in this present study from the receiving water bodies, e.g. Hadis and Devi (2007) $(4.1 \mathrm{mg} / \mathrm{l})$ showed high phosphate concentrations than that obtained in this study (0.78 - $0.82 \mathrm{mg} / \mathrm{l})$. According to Bliefert and ANNON N [10], phosphates concentrations are within the standard limit, therefore this parameter did not cause change or pollution to the receiving water bodies. The presence of $\mathrm{PO}_{4}^{3-}$ in water increases eutrophication and similarly promotes the growth of algae. The difference in $\mathrm{PO}_{4}^{3-}$ observed in downstream sites could be to different effluent quantities discharged into the receiving water bodies from wet coffee processing factories in major coffee growing ecological zones in Burundi.

The chlorides concentrations at the upstream and downstream sites were in the range of $15.7-36.9 \mathrm{mg} / \mathrm{l}$ with a mean of $27.7 \pm 7.96 \mathrm{mg} / \mathrm{l}$ and $28.9-45.8 \mathrm{mg} / \mathrm{l}$ with a mean of $35.1 \pm 5.54 \mathrm{mg} / \mathrm{l}$ respectively during wet season whereas varied from $17.0-46.1 \mathrm{mg} / \mathrm{l}$ with a mean of $29.4 \pm 7.99 \mathrm{mg} / \mathrm{l}$ and $28.1-55.2 \mathrm{mg} / \mathrm{l}$ with a mean of $37.1 \pm 8.84 \mathrm{mg} / \mathrm{l}$ downstream during wet and dry seasons. High $\mathrm{Cl}^{-}$ concentrations found at downstream of the discharged points could be due to wet coffee effluents discharged without any treatment. However, the effluents qualities appeared to be compliant with the standards. Thus, the chloride parameter indicated that water was appropriate for direct use [19].

The nitrate concentrations were in the range of downstream of rivers water were in the range of $3.94-21.3 \mathrm{mg} / \mathrm{l}$ with a mean of $10.3 \pm 4.15 \mathrm{mg} / \mathrm{l}$ and 1.21 $16.7 \mathrm{mg}$ with a mean of $4.23 \pm 2.26 \mathrm{mg} / \mathrm{l}$ respectively during wet and dry seasons. The results show that the results of the current study agree with findings reported by Haddis A. \& Devi R., 2008 [1]. These values show wide variations between samples from different sites and differed significantly $(\mathrm{p}<0.05)$. Whereas at upstream Nitrate concentrations were in the range of $0.17-11.3 \mathrm{mg} / \mathrm{l}$ with a mean of $6.28 \pm 4.04 \mathrm{mg} / \mathrm{l}$ and $0.38-3.16 \mathrm{mg} / \mathrm{l}$ with a mean of $1.45 \pm 0.91 \mathrm{mg} / \mathrm{l}$ 
respectively during the months of April and June. Based on the WHO (1995) standard, the nitrates concentrations along downstream sites were in conformity with the acceptable river water quality [10] [11] [16], which indicated that the wet coffee processing factories effluents did not contribute to the pollution of the receiving water bodies. The low nitrates concentrations at downstream sites for the results recorded in dry seasons as compared to wet season may be due the decreasing of the use of fertilizers in the surrounding fields by famous which came to rivers water by runoff [4].

The ammonium concentrations were in the range of $2.92-9.54 \mathrm{mg} / \mathrm{l}$ with a mean of $5.55 \pm 2.23 \mathrm{mg} / \mathrm{l}$ and $1.62-3.96 \mathrm{mg} / \mathrm{l}$ with a mean of $2.90 \pm 0.77 \mathrm{mg} / \mathrm{l}$ downstream sites respectively during wet and dry seasons. The results show that the results of the current study agree with findings reported by Dejen YemaneTekle et al., 2015 [15] and Ejeta, T. M., \& Haddis, A. (2016) [19]. In the upstream sites, ammonium concentrations were in the range $1.08-8.10 \mathrm{mg} / \mathrm{l}$ with a mean of $4.15 \pm 2.06 \mathrm{mg} / \mathrm{l}$ and $0.72-2.88 \mathrm{mg} / \mathrm{l}$ with a mean of $1.55 \pm 0.78 \mathrm{mg} / \mathrm{l}$ respectively in wet and dry seasons. There was significant difference in $\mathrm{NH}_{4}^{+}$ recorded in both periods (April and June seasons). The general trend observed was increasing in Ammonium concentrations in downstream sites and this might be due to coffee wastewater effluents released from wet coffee processing factories in major coffee growing ecological zones in Burundi without any treatment [4].

$\mathrm{NO}_{2}^{-}$concentrations were in the range of $0.05-0.39 \mathrm{mg} / \mathrm{l}$ with a mean of $0.18 \pm 0.13 \mathrm{mg} / \mathrm{l}$ and $0.01-0.08 \mathrm{mg} / \mathrm{l}$ with a mean of $0.03 \pm 0.02 \mathrm{mg} / \mathrm{l}$ downstream sites respectively during the months of April and June coffee processing times whereas at the upstream, Nitrites concentrations were almost below the limit of detection. The increase in $\mathrm{NO}_{2}^{-}$concentrations at downstream sites during wet and dry seasons was due to the concentrations from wet coffee processing factories effluents in Kayanza coffee growing ecological zones in $\mathrm{Bu}$ rundi. The nitrites values of the samples from all the sites were below the recommended WHO standards and overall assessment and classification of stagnant and running surface water according to their quality of river water [4]. There was no significant difference in nitrite recorded in both seasons (wet and dry seasons).

In Kayanza growing ecological zones, the copper values for all the samples in kayanza during dry season did not exceed the limit of detection of AAS. In this case, the coffee effluents from all locations did not contribute to water pollution in studied areas [4]. The concentrations of $\mathrm{Cu}$ were within the permissible limit standards and o overall assessment and classification of stagnant and running surface water according to their quality of river water [10] [11].

Copper is acutely toxic to most of forms of aquatic life at relatively low concentrations. Increased quantities of copper make water distasteful to drink. The copper values for all the samples in Kayanza during sampling periods did not exceed the limit of detection of AAS. Lead is a toxic element that accumulates in 
the skeletal structures. The toxic effects of $\mathrm{Pb}$ to fish decrease with increasing water hardness and dissolved oxygen [20] [21].

\section{Conclusion}

Wet coffee processing factories in Kayanza coffee growing ecological zone contain large amounts of organic and nutrient load. This huge untreated wastewater is discharged directly into the nearby pits that are intended to serve as waste stabilization ponds but are neither appropriately constructed to accommodate the generated waste during peak processing time and some wet coffee factories discharged directly their coffee effluent into nearby water bodies. This leads to overflow of raw effluents into natural watercourses and damages the surface waters and aquatic life. The findings show that coffee wastewater discharged without any treatment contributes to the pollution of receiving water bodies. Therefore, the coffee wastewater generated around the rivers was found to have a great negative impact on the receiving water bodies' quality, hence extra care has to be taken in order to protect the receiving water bodies from being polluted. Laws and policies should be enforced to ensure the parameters of the wastewater are within the set standards in order to safeguard the environment.

\section{Acknowledgements}

The authors would like to thank ISABU and the Project to Support the Competitiveness of the Coffee Sector (PACSC) in Burundi (PJ-002598) for financial support. Wet coffee processing factory managers in Kayanza zone for cooperation during coffee wastewater and water sampling are also acknowledged. Our sincere thanks go to the staff of Soil and Food Products Analysis Laboratory (LASPA) at ISABU for technical assistance during data collection. We are also grateful to IEET for its academic guidance.

\section{Conflicts of Interest}

The authors declare no conflicts of interest regarding the publication of this paper.

\section{References}

[1] Haddis, A. and Devi, R. (2008) Effect of Effluent Generated from Coffee Processing Plant on the Water Bodies and Human Health in Its Vicinity. Journal of Hazardous Materials, 152, 259-262. https://doi.org/10.1016/j.jhazmat.2007.06.094

[2] Flores, M., Andrew, S. and Paul, H. (2013) Coffee Clearwater Revival: Protection Water Resources in Coffee Producing Areas of Central America. The Specialty Cof fee Association of America (SCAA) Event, Boston, 11-14 April 2013, 1-12.

[3] Technoserve (2011) The Coffee Initiative: Phase One Final Report. Technoserve.

[4] Bisekwa, E., Njogu, P.M. and Kufa-Obso, T. (2020) Effluent Quality of Wet Process Coffee Processing Factories in Coffee Growing Ecological Zones in Burundi. International Journal of Water and Wastewater Treatment, 6, 1-7. https://sciforschenonline.org/journals/water-and-waste/IJWWT176.php 
[5] Beyene, A., Yared, K., Taffere, A., Fassil, A., et al. (2012) The Impact of Traditional Coffee Processing on River Water Quality in Ethiopia and the Urgency of Adopting Sound Environmental Practices. Environmental Monitoring and Assessment, 10, 7053-7063. https://doi.org/10.1007/s10661-011-2479-7

[6] Bambi, S., Elizabeth, B., Joanne, S. and Mirielle, C.W. (2012) Assessment of the Starbucks Coffee and Farmer Equity (C.A.F.E) Practices Program FY08-FY10. Conservation International, Arlington.

[7] Brando \& Carlos (2012) The Use of Water in Processing: Treatment, Conservation and Impacts on Quality. The Specialty Coffee Chronicle (3).

[8] Mugenda, O.M. and Mugenda, A.G. (2003) Research Methods, Qualitative and Quantitative Approaches. Acts Press, Nairobi.

[9] APHA (2005) Standard Methods for the Examination of Water and Wastewater. 21st Edition, American Public Health Association, APHA-AWWWA-WEF, Washington DC.

[10] Annon, N. (1989) Memento technique de l'Eau, Tome 1, Bubl. Signement. Distr. Lavoisier, Technique et Documentation, Paris. 8.

[11] Bliefert, C. and Perraud, R. (2001) Chimie de l'environnement: Air, Eau, Sols et Déchets. Deboeck Université, Paris.

[12] AFNOR (1997) Qualité de l'eau. Recueil des normes Françaises Environnementales. Tomes 1, 2, 3 et 4 . Paris.

[13] Ejeta, T.M. and Haddis, A. (2016) Assessment of the Effect of Effluent Discharge from Coffee Refineries on the Quality of River Water in South-Western Ethiopia. African Journal of Environmental Science and Technology, 10, 230-241. https://doi.org/10.5897/AJEST2015.1886

[14] Li, D. and Liu, J. (2019) Water Quality Detection for Lakes. In: Li, D. and Liu, S., Eds., Water Quality Monitoring and Management, Academic Press, Cambridge, 221-231. https://doi.org/10.1016/B978-0-12-811330-1.00008-9

[15] Yemane, T.D., Abebe, B.H., Taffere, A.W. and Azeb, G.T. (2015) Effect of Coffee Processing Plant Effluent on the Physicochemical Properties of Receiving Water Bodies, Jimma Zone Ethiopia. Americn Journal of Environmantal Protection, 4, 83-90. https://doi.org/10.11648/j.ajep.20150402.12

[16] WHO (1995) Guidelines for Discharge of Industrial Effluent Characteristics. 231-236.

[17] Sewe, H. (2010) A Study on the Efficiency of Dandora Domestic and Industrial Wastewater Treatment Plant in Nairobi, Kenya. 53-112.

[18] Saral, A. and Goncaloğlu, B.I. (2008) Determination of Real COD in Highly Chlorinated Wastewaters. Clean-Soil, Air, Water, 36, 996-1000.

https://doi.org/10.1002/clen.200800073

[19] Mussatto, S.I., Carneiro, L.M., Silva, J.P.A., Roberto, I.C. and Teixeira, J.A. (2011) A Study on Chemical Constituents and Sugars Extraction from Spent Coffee Grounds. Carbohydrate Polymers, 83, 368-374. https://doi.org/10.1016/j.carbpol.2010.07.063

[20] Njogu, P.M., Keriko, J.M., Wanjau, R.N. and Kitetu, J.J. (2011) Distribution of Heavy Metals in Various Lake Matrices; Water, Soil, Fish and Sediments: A Case Study of the Lake Naivasha Basin, Kenya. Journal of Agriculture, Science and Technology, 13, 91-106.

http://journals.jkuat.ac.ke/index.php/jagst/article/view/140/141

[21] Orwa, T.O., Kiptoo, J., Onditi, A. and Njogu, P.M. (2014) Assessment of Selected Native Plants Growing along Nairobi River for Uptake of Copper, Zinc and Cadmium. Journal of Agriculture, Science and Technology, 16, 1-10. 